\title{
The Geothermal Progress Monitor:
}

\section{System Status and Operational Experience}

\author{
R. E. Gerstein \\ L. D. Kenkeremath \\ M. B. Murphy \\ D. J. Entingh
}

March 1982

MTR-82W73

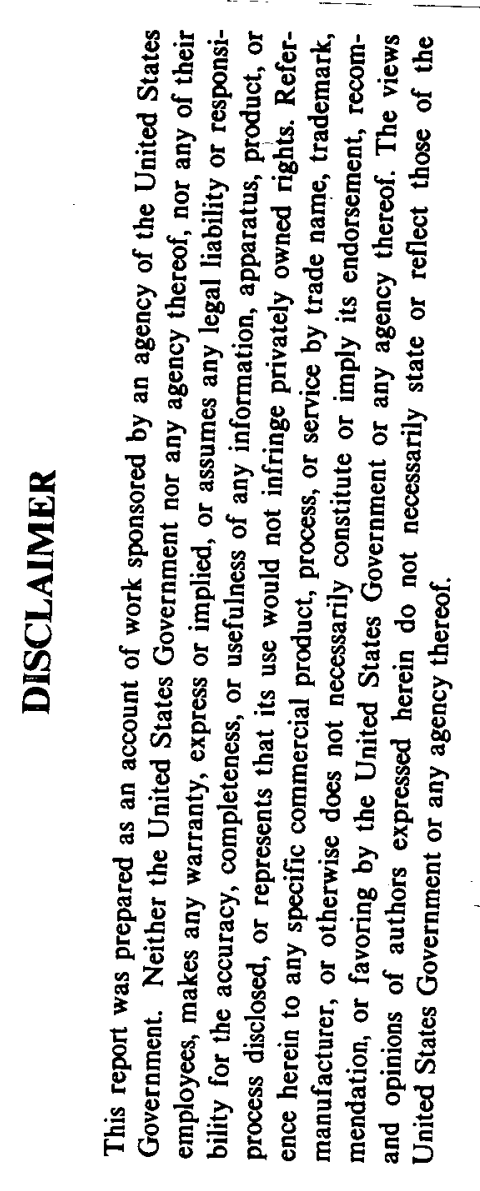

SPONSOR:

Division of Geothermal and Hydropower Technologies

U.S. Department of Energy

CONTRACT NO.:

DE-AC01-81RA50563

DISTRFAUTOR OF THIS DOCEMEET IS UALLMITED

The MITRE Corporation

Metrek Division

1820 Dolley Madison Boulevard

McLean, Virginia 22102 


\section{DISCLAIMER}

This report was prepared as an account of work sponsored by an agency of the United States Government. Neither the United States Government nor any agency Thereof, nor any of their employees, makes any warranty, express or implied, or assumes any legal liability or responsibility for the accuracy, completeness, or usefulness of any information, apparatus, product, or process disclosed, or represents that its use would not infringe privately owned rights. Reference herein to any specific commercial product, process, or service by trade name, trademark, manufacturer, or otherwise does not necessarily constitute or imply its endorsement, recommendation, or favoring by the United States Government or any agency thereof. The views and opinions of authors expressed herein do not necessarily state or reflect those of the United States Government or any agency thereof. 


\section{DISCLAIMER}

Portions of this document may be illegible in electronic image products. Images are produced from the best available original document. 

ABSTRACT

The Geothermal Progress Monftor (GPM) system was designed and implemented by MITRE for DOE's Division of Geothermal Energy (now the Division of Geothermal and Hydropower Technologies). This report summarizes MITRE's operational experience with the system and provides a qualitative assessment of its data sources. 

. 
TABLE OF CONTENTS

Page

LIST OF ILLUSTRATIONS

LIST OF TABLES

EXECUTIVE SUMMARY

vi

vi

vii

1.0 INTRODUCTION

1

1.1 Background

1.2 Purpose and Objectives

1.3 General Constraints on the GPM System

2

4

2.0 DESIGN AND OPERATIONAL EXPERIENCE, 1981-1982 7

2.1 Geotherma1 Progress Monitor Reports . 7

2.2 MITRE Special Analyses

3.0 QUALITATIVE ASSESSMENT OF THE GPM SYSTEM 15

3.1 Government and Government-supported Sources

3.2 Commercial and Trade Sources

APPENDIX: COMMERCIAL AND TRADE PUBLICATIONS USED BY THE GPM SYSTEM 


\section{LIST OF ILLUSTRATIONS}

Figure Number

Page

1

Schematic of Information Flow in the

Geothermal Progress Monitor

3

The Geothermal Progress Monitor Information Network, 1981

3

Information Flow at MITRE

18

\section{LIST OF TABLES}

Table Number

1

Reproduction of the Table of Contents of GPM Report Number 5

2

Reproduction of the Table of Contents of GPM Report Number 6

Page

Reproduction of the Table of Contents of GPM Report Number 7

4

Reproduction of the Table of Contents of GPM Report Number 8 


\section{EXECUTIVE SUMMARY}

The Geothermal Progress Monitor (GPM) is an information system designed and implemented by The MITRE Corporation on behalf of the Division of Geothermal and Hydropower Technologies (DGHT, formerly Division of Geothermal Energy) of the U.S. Department of Energy (DOE). The GPM serves a dual function for DGHT and other members of the Interagency Geothermal Coordinating Council (IGCC). It supports effective management of the federal geothermal program and it provides information for executive, legislative, statutory, and public needs.

The overall purpose of the GPM is to identify and quantify trends in the development and use of geothermal energy resources. Its general objective is to provide a quick-response, centralized, geothermal information collection, storage, analysis, and reporting system that tracks the development of geoţhermal energy in the United States and the world.

Data is collected via the GPM network and is reported periodically as a Geothermal Progress Monitor Report. These reports receive wide distribution to organizations and participants in the GPM system and others in the geothermal industry. During calendar year 1981 and through the first quarter of 1982, four Geotherma1 Progress Monitor Reports were submitted to DOE for publication. Despite minor format variations, these four reports maintained the overall objective of the system, i.e., they have identified and quantifled trends in the development and use of geothermal energy.

The collected data has also been used to support several special analyses. These included:

- Inputs to the IGCC Fifth Annual Report

- An estimate of near-term contributions from geothermal energy

- A feature item in GPM Report Number 5 on geothermal ethanol plants

- An estimate of U.S. industry investment in geothermal energy activities

The information sources for the GPM system include government or government-supported contractors and commercial or trade publications and contacts. At the Department of Energy, DGHT is the driving force behind the system. The DOE Operations offices in the West, supported by EG\&G Idaho and the Oregon Institute of Technology, 
are the main sources for direct reports from the field. In the Department of the Interior, the Geologic Division of the U.S. Geological Survey provides information about the geothermal resources. The Minerals Management Service supplies DGHT, MITRE and the Lawrence Berkeley Laboratory with information about leasing, environmental assessments, and plans of operation.

The network of government-sponsored sources is supplemented by geothermal trade publications and newsletters to which MITRE subscribes. The MITRE Corporation's role is to integrate the assembled data, to maintain comprehensive project files, and to prepare the GPM Reports, trend and/or special analyses. 


\subsection{INTRODUCTION}

The Geothermal Progress Monitor (GPM) is an information system designed and implemented by The MITRE Corporation on behalf of the Division of Geothermal and Hydropower Technology (DGHT, formerly Division of Geothermal Energy) of the U.S. Department of Energy (DOE). Its purpose is to keep track of and to report significant events and trends in the U.S. geothermal industry and the federal geothermal program. The information sources of the GPM system are paper and computerized files maintained by a number of organizations throughout the United States. Trade and technical publications are also used to supplement the information-gathering network. Periodic reports from the GPM system consist mainly of manual and computerized analyses of the collected data. In addition, significant events and activities are usually highlighted.

The GPM serves a dual function for DGHT and other members of the Interagency Geothermal Coordinating Council (IGCC). It supports effective management of the federal geothermal program and it provides information for executive, legislative, statutory, and public needs.

The design and implementation of the GPM has been described in MITRE report MTR-80W75 (1981). This paper is a report on the current status of the GPM system and a summary of MITRE's operational experience during calendar year 1981 and the first quarter of 1982. It includes a description of the required output and the mechanism by which the information is gathered, integrated, and published as a Geothermal Progress Monitor Report.

\subsection{Background}

In 1978 the DOE geothermal energy program was recognized as a priority area for rapid energy technology development. The Division of Geothermal Resource Management (DGRM) was established in October of 1978 to promote geothermal energy technology and development throughout the nation. In February 1980, DGRM was merged back into the Division of Geothermal Energy (DGE, now DGHT), which continues the mandate of DGRM.

The design of the GPM began in 1975, when MITRE was asked to develop system concepts for monitoring the development and use of geothermal energy in the United States. The results of this study were published in February 1977 as MITRE report MTR-7307. No further action was taken until February 1979, when a panel of the DGRM Commercialization Workshop developed the rationale for a progress monitoring system and described a preferred approach for its 
development. The panel evaluated a number of concepts and in July 1979, MITRE was tasked to develop and implement the GPM.

MITRE's review of the background, approaches, and objectives provided a focus for discussion at a meeting of geothermal database managers convened by DGRM in August 1979. The results of this meeting served as a basis for developing an initial GPM design and a proposed first report of the GPM. These design and proposed first report were reviewed at a meeting of DGRM field elements in November 1979, and a consensus was reached to produce the GPM report on a trial basis for three issues. GPM Report Number 1 was 1 ssued in January 1980. The trial edition of three reports proved to be so successful that, by September 1980 , a fourth report had been prepared and issued to interested parties in both government and industry.

Production of GPM Report Number 5 began in February 1981; it was issued in June 1981. One additional GPM report was prepared during 1981 and two reports were prepared during the first quarter of 1982 .

\subsection{Purpose and Objectives}

The overall purpose of the GPM is to identify and quantify trends in the development and use of geothermal energy resources. To achieve this purpose, information from several sources is collected, analyzed for status indicators and trends, and reported to users. A schematic representation of the information network is given in Figure 1.

The general objective of the GPM is to provide a quick-response, centralized, geothermal information collection, storage, analysis, and reporting system that tracks the development of geothermal energy in the United States and the world. It assists the Director of DGHT in reporting geothermal energy activities, status, and trends to other officials in the government, field members of the DGE State Geothermal Commercialization Teams, and other interested parties in the geothermal industry.

The intent is to collect and analyze a complex set of progress indicators from a wide variety of sources to produce a coherent, timely, and accurate picture of the status and rate of geothermal. energy development. Principal emphasis is placed on developments of the resources and technological advances in the geothermal industry. The principal policy-oriented aim is to detect the degree to which the United States' geothermal energy program has affected the growth of geothermal energy use and to assure that federal programs and policies meet the needs of actual geothermal development. With 


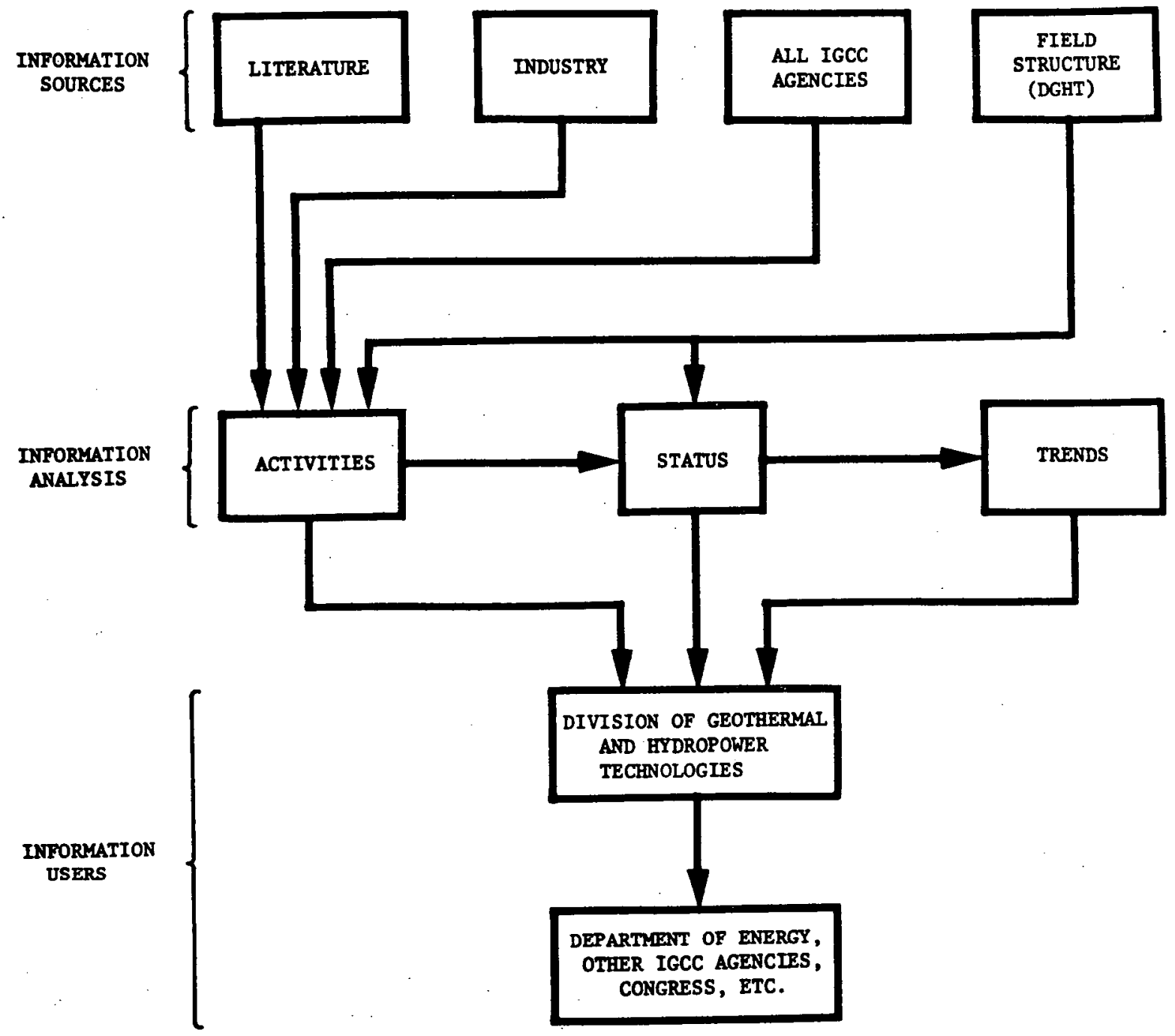

FIGURE 1

SCHEMATIC OF INFORMATION FLOW IN THE

GEOTHERMAL PROGRESS MONITOR 
regard to the private sector, the aim is to provide industry with information for its own geothermal development decision-making processes.

The specific objectives of the GPM are to:

- Monitor and report on geothermal development activities, status, and trends in the government and private sector by locating, quantifying, and analyzing public and private sector plans and actions

- Serve the program management and information dissemination functions of DGHT and the IGCC

- Serve as a national point of reference for reporting the pace of geothermal development

- Provide site-specific development status information to the Geothermal Site Development Forecasting System

\subsection{General Constraints on the GPM System}

The following concerns and constraints have been used to bound the scope of the GPM system:

- It is driven in the near term by DGHT's need to report to the member agencies of the IGCC, to the upper levels in DOE, and to the DGHT State Geothermal Commercialization Teams.

- It uses existing information bases, rather than trying to build a new, large information base.

- It maximizes the use of a number of different existing sources of information.

- It maximizes access to the system by both people in the geothermal headquarters groups and people in the field.

- It minimizes duplication of effort with respect to the collection, analysis, and storage of information at various places around the U.S.

- It uses feedback from the DGHT State Geothermal Commercialization and Resource Teams as the primary basis for validating the accuracy of the information in the GPM.

The reporting vehicle, the GPM Report, is published periodically. It is prepared by MITRE, with DGHT retaining editorial 
control over activity reports. MITRE is responsible for and retains editorial control for estimates of the accuracy of the reported data, for the ranges of status indicators reported, and for trend analyses. 


$$
\text { (2) }
$$




\subsection{DESIGN AND OPERATIONAL EXPERIENCE, 1981-1982}

The design of the Geothermal Progress Monitor system has been described in MITRE report MTR-80W075 (1981). In general, fifteen topical areas have been identified. These provide a comprehensive overview of the geothermal energy field. For each of these topics up to three types of information are developed: (1) events, or activities, (2) status, or the present situation, and (3) trends that are identified or synthesized from the first two types of information.

The collected information is reported periodically, as a Geothermal Progress Monitor Report. These reports receive wide distribution to organizations and participants in the GPM system and others in the geothermal industry.

The data collected via the GPM network has also been used to support several special analyses. Typically, these analyses have been used as draft material for the IGCC Fifth Annual Report and as background data to support congressional testimony or responses to executive and congressional queries.

\subsection{Geothermal Progress Monitor Reports}

During calendar year 1981 and through the first quarter of 1982, four Geothermal Progress Monitor Reports have been submitted to DOE for publication. For comparative purposes the tables of contents of the four reports are reproduced as Tables 1 through 4. These four reports have maintained the overall objective of the system; $i . e .$, they have identified and quantified trends in the development and use of geothermal energy by synthesizing activity and status reports from the field. The minor format variations that have occurred have been introduced to maintain the interest of the analysts/authors and readers of the reports. The format has also varied slightly to allow for the incorporation or highlighting of the results of other studies as they become available. These include some of the special analyses that were conducted at the request of DGHT.

\subsection{MITRE Special Analyses}

Inputs to IGCC Fifth Annual Report

Early in 1981, inputs to the Fifth Annual Report of the Interagency Geothermal Coordinating Council were prepared in a draft form. MITRE report WP-81W107 presented a survey of activities by state and local governments and Indian tribes in the development of geothermal resources in 1980. This material had been collected by way of the GPM information-gathering network. The paper also 
TABLE 1

REPRODUCTION OF THE TABLE OF CONTENTS

OF GPM REPORT NUMBER 5

\section{PREFACE}

EXECUTIVE SUMMARY

1.0 ELECTRIC USES

2.0 DIRECT HEAT USES

3.0 DRILLING ACTIVITIES

4.0 EXPLORATION

5.0 LEASES

6.0 OUTREACH AND TECHNICAL ASSISTANCE

7.0 FEASIBILITY STUDIES AND APPLICATION DEMONSTRATIONS

8.0 LOAN GUARANTY PROGRAM

9.0 R\&D ACTIVITIES

10.0 LEGAL, INSTITUTIONAL, AND REGULATORY ACTIVITIES

11.0 ENVIRONMENTAL ACTIVITIES

12.0 STATE, LOCAL, AND PRIVATE SECTOR ACTIVITIES

13.0 REPORTS AND PUBLICATIONS

14.0 DIRECTORY

GLOSSARY 
TABLE 2

REPRODUCTION OF THE TABLE OF CONTENTS

OF GPM REPORT NUMBER 6

PREFACE

FOREWORD

I. STATE STATUS SUMMARIES

Alaska

Arizona

California

Colorado

Hawail

Idaho

Montana

Nevada

New Mexico

North Dakota

Oregon

South Dakota

Texas

Utah

Washington

Wyoming

II. RECENT MAJOR ACTIVITIES (GENERAL)

III. REPORTS AND PUBLICATIONS

IV. DIRECTORY 
TABLE 3

REPRODUCTION OF THE TABLE OF CONTENTS

OF GPM REPORT NUMBER 7

FOREWORD

I. SITE STATUS SUMMARIES

A. Known Geothermal Resource Areas with High Levels of Development Activity

B. Known Geothermal Resource Areas with Moderate Levels of Development Activity

c. Known Geothermal Resource Areas with Low or No Development Activity

II. COMPARISON OF GEOTHERMAL ELECTRIC FORECASTS

III. RECENT MAJOR ACTIVITIES
A. Electric Power
B. Direct Heat
C. Drilling and Exploration
D. Leases
E. Lega1, Institutiona1, and Regulatory Activities
F. Research and Development
G. Environment

IV. REPORTS AND PUBLICATIONS

STATE COMMERCIALIZATION TEAMS (DIRECTORY) 
TABLE 4

REPRODUCTION OF THE TABLE OF CONTENTS

OF GPM REPORT NUMBER 8

PREFACE

I. DIRECT HEAT STATUS UPDATE

II. RECENT MAJOR ACTIVITIES

III. REVIEW OF MAJOR ACTIVITIES, 1981

IV. REPORTS AND PUBLICATIONS

V. DIRECTORY 
included a summary of the private sector's progress in geothermal development in 1980. To supplement the collected activity reports, a table of geothermal wells by type and company was compiled from a computerized data file (GEOWELLS) designed and maintained by MITRE expressly for the GPM. The industry's plans for future developments were also reported.

\section{Near-term Contributions from Geothermal Energy}

At the request of the Division of Geothermal Energy (now the Division of Geothermal and Hydropower Technologies), MITRE prepared an estimate of the United States' existing geothermal energy capacity and the additions planned in the near term (WP-81W154). MITRE's automated files of the GPM system were used to assemble the data on electric and direct-heat use projects. In addition, a distinction was made between those projects that were stimulated by federal actions compared to those that appeared to have received no federal stimulus.

\section{Geothermal Ethanol Plants}

An interesting application of moderate temperature geothermal resources is to provide process heat for alcohol distillation. The status of U.S. geothermal ethanol plants was reviewed in MITRE report WP-81W399. Included in this paper was a discussion of the federal economic incentives avallable for fuel alcohol facilities using biomass feedstock and geothermal process energy. This analysis was included in the "Direct Heat" section of GPM Report Number 5, June 1981.

\section{Geotherma1 Industry Investment Analysis}

Responding to a request from DGHT, MITRE prepared an estimate of U.S. industry investment in geothermal energy activities for 1980 and 1981. This analysis (WP-82W93) used information and statistics collected by the Geothermal Progress Monitoring System and residing in the paper and computerized data files at MITRE. The total (equity plus debt) pre-tax investment was estimated to be about $\$ 185$ miliion in 1980 and about $\$ 235$ million in 1981 . The following six investment categories were included in the analysis.

- Leasing costs (rents, bonus bids)

- Exploration costs excluding deep well drilling

- Deep well drilling

- Power plant construction 
- Research and development sponsored by the Electric Power Research Institute

- Direct heat projects

\section{Update of Direct Heat Projects File}

MITRE has established and built up a computerized data file of direct heat projects (GEOHEAT). This file was updated in 1981 through a significant effort of collecting data from the field components of the GPM system. This effort has resulted in what appears to be the most comprehensive and authoritative file of descriptions of geothermal direct heat projects in the United States. There are over 600 project descriptions in the file.

The GEOHEAT update process was begun in early 1981, with discussions between MITRE and other members of the Geothermal Progress Monitor system about what kind of information would be both useful and acquirable from the field. Discussions at the Federal and State Geothermal Conference at Seattle in January led to the agreeement that if MITRE would transform the contents of the earlier GEOHEAT file into an updatable survey form, then the DOE Regional offices would get the State Geothermal Commerclalization Teams to update the information on those forms and add descriptions of projects not covered in the original database. This update was to be, and was in fact, based on the general information that each Commercialization Team had collected in the previous year, rather than based on an expensive, exhaustive field survey process.

The information was sent out to the Regional offices in July and transmitted from them to the State Teams. Information began trickling back to MITRE in September of 1981. The flow was unfortunately interrupted by the closing of the DOE Regional Offices on October 1, 1981. The coding process was started, however, and good information returns were obtained from all western states except California by the end of February 1982, when the coding process was frozen. The coding process was completed in mid-March 1982 , and statistics were pulled from the file (which is now called "GEOHEAT-V3.0") to be inserted into GPM Report Number 8. 


\subsection{QUALITATIVE ASSESSMENT OF THE GPM SYSTEM}

The GPM system is dependent on the quality and reliability of its information and sources. Generally, the sources fall into two categories: government or government-supported contractors and commercial or trade publications and contacts. Section 3.1 discusses those organizations which are considered government contacts and section 3.2 describes the commercial and trade publications which are used to provide data input. The publishing offices of these trade journals are listed in the Appendix. Figure 2 is an overall schematic of the information-gathering network of the GPM system as it existed during 1981 .

\subsection{Government and Government-supported Sources}

The Department of Energy

The Division of Geothermal and Hydropower Technologies (DGHT) is the primary driving force behind the GPM system. The GPM reports are prepared for and reviewed by DGHT and the spectal analyses are furnished at their request. DGHT also serves as an information source for the GPM. Progress reports pertaining to DOE-funded projects are transmitted directly to DGHT and, in turn, forwarded to MITRE to be included in the GPM system.

The DOE Operations Offices in the West are supported by EG\&G Idaho and the Oregon Institute of Technology. These two centers provide monthly reports of geothermal activities in the western states. The reports are generally quite comprehensive and include information about each center's activities as well as information supplied by state energy offices and other local entities. The reports are submitted to DGHT Headquarters and MITRE where the most significant elements are selected for inclusion in a GPM report.

The Department of the Interior

The Department of the Interior contributes substantial amounts of information to the GPM system. The Geologic Division of the U.S. Geological Survey (USGS) is responsible for resource assessment projects and reports its findings to DGHT, Lawrence Berkeley Laboratory (LBL), and the University of Utah Research Institute. The Minera1s Management Service (formerly the Conservation Division of the USGS) provides information about leasing, environmental assessments, and plans of operation to DGHT, MITRE, and LBL. This data set is among the most valuable in that it signals the level of interest in a particular area and identifies the parties responsible for developing a prospect. 


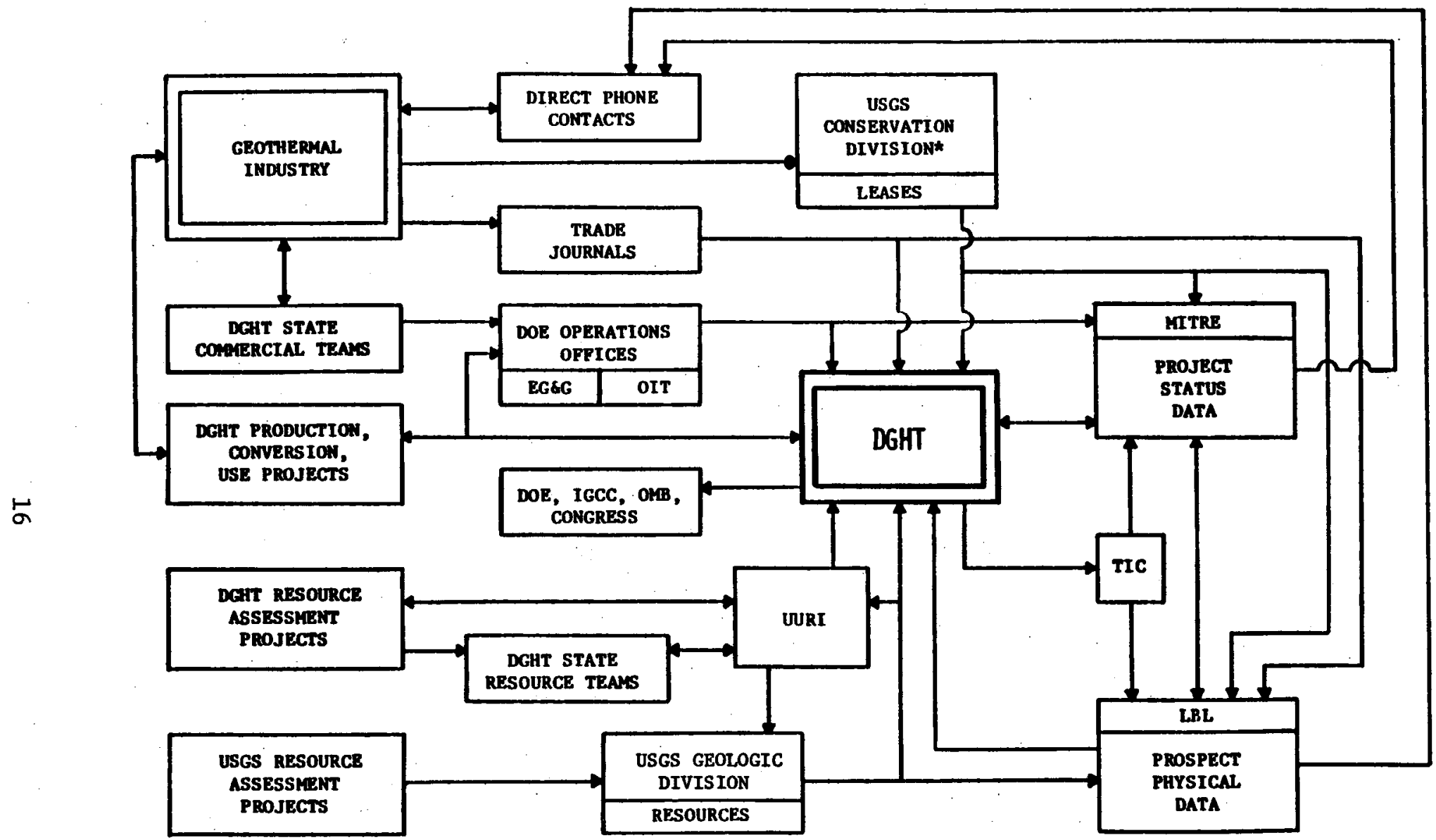

*Established as Minerals Management Service, 1982.

FIGURE 2

THE GEOTHERMAL PROGRESS MONITOR

INFORMATION NETWORK, 1981 
Lawrence Berkeley Laboratory

The Lawrence Berkeley Laboratory at the University of Cal1fornia also receives data from DOE, MITRE, TIC, trade journals, and direct telephone contacts. The primary role of LBL is to maintain the Geothermal Resource Areas Database (GRAD). This database is concerned with the physical characteristics of geothermal prospects. It has been upgraded by the inclusion of MITRE's GEOWELLS and GEOHEAT files and is now a valuable interactive element of the GPM system.

\section{MITRE}

The MITRE Corporation's role in this system is to integrate the data assembled from the various sources and to maintain comprehensive project status files. The information is then avallable for the GPM reports, trend and/or special analyses. Figure 3 is a schematic representation of the information flow at MITRE.

\subsection{Commercial and Trade Sources}

\section{Petroleum Information Corporation}

The Petroleum Information Corporation (PIC) collects data on matters pertaining to the oil and gas industry. It operates, on a subscription basis, two vital geothermal data sources. The "National Geothermal Service" (NGS) is a weekly update of all geothermal drilling activity. The drilling information is presented in tabular form by state (California in turn is divided into regions) and includes completions, first reports, and progress reports. Each issue is usually introduced by a 2 to 4 page summary of the past week's events in the geothermal industry. Typically, these news sum- marles include information about exploration programs or plans, drilling successes or failures, announcements of power plants, direct heat projects, and lease sales. The NGS provides frequent, highly reliable information to the GPM system. It has been used extensively to construct and maintain the GEOWELLS data file at MITRE.

The second geothermal data source offered by PIC is the monthly Geothermal Well Completion Cards service. As the completion of a geothermal well is announced, the pertinent information relating to its location, owner, driller, physical characteristics, and drilling history is compiled on a $4 \times 6$ file card. These cards are distributed to subscribers and are a valuable cross reference to the weekly NGS newsletter. They have been used to verify information in the GEOWELLS data file. 




NOTES:

C - Computer-based File

I = Printed In GPM Reports

III - Source for Spectal Analyoed

II - Basis for Trend Analyses

IV = Internal Project Refor

FIGURE 3

INFORMATION FLOW AT MITRE 
The Geothermal Resources Council

The Geothermal Resources Council (GRC) is the professional association of the geothermal industry. It publishes the Geothermal Resources Council Bulletin 11 times per year. A typical issue includes a feature article about a potential resource area or some aspect of geothermal development (e.g., financing), an editorial, a survey of state and federal activities, and sections devoted to announcements of lease sales, reviews of publications, and notices of forthcoming meetings. The GRC Bulletin is generally reliable, and its feature articles provide authoritative insights into various aspects of the geothermal industry. The summary and survey information tends to confirm and, in some instances, enhance information reported by the DOE Regional Operations Offices.

The Geyser

"The Geyser" is an international geothermal energy newsletter published 18 times per year. Each four-page issue focuses on three or four major news 1 tems of interest to the geothermal community. It also includes short items such as drilling notices or impending lease sales. Although not as comprehensive as some of the other publications used by the GPM system, it does provide in-depth information about the activities and events included in each issue.

\section{Geotherma1 Energy}

Geothermal Energy is a monthly publication of Geothermal World Corporation. It is similar in nature to the GRC Bulletin, but seems to focus more on the international and business communities. Throughout the year it will publish special summary articles dealing with specific areas of geothermal development (e.g.,. annual drilling summary). Although there is significant intrinsic value to the information contained in Geothermal Energy, its printing and circulation schedule is somewhat erratic. This reflects on the timeliness of the information contained in each issue.

\section{IBS Newspaper Clipping Service}

During the first half of calendar year 1981, the International Business Systems (IBS) clipping service supplied weekly inputs to the GPM system. The clipping service provided geothermal-related newspaper articles from most of the western states. In some instances the technical details may have been garbled, but this was a function of the reporting and not the clipping service. The data input was the most timely next to the method of direct telephone contact. Unfortunately, the DOE contract with IBS was not renewed during 1981 . 


\section{Direct Contacts}

One aspect of geothermal progress monitoring is the determination of activities affecting geothermal power plant development. More than any other class of project, the information for this data set has been gathered by direct telephone contacts with developers and utilities. The initial information about new power-plant construction or additions may be derived from the more conventional sources such as the newsletters or journals. In order to carry out the trend and special analyses, however, it is sometimes necessary to develop more detailed and more specific information. MITRE maintains a computerized data file named GEOWATTS which is a comprehensive listing of existing and proposed power plants. It contains identification data as well as data relating to plant size, plant type, estimated power-on-line date, and estimated plant cost. Add1tional information is collected and maintained in a site status file.

The combination of the GEOWATTS data file, the site status file and the GEOWELLS data file has enabled the Geothermal Progress Monitor staff to assemble detailed site histories of geothermal power-plant development. These histories provide primary data input for the GEOTHERMAL SITE DEVELOPMENT FORECASTING SYSTEM (FORSITE). The conceptual design of this system is described in MITRE report MTR-80W79, March 1980 and its development status is reported in MTR-82W79 (in preparation). 


\section{REFERENCES}

1. Assistant Secretary for Conservation and Renewable Energy, Division of Geothermal Energy, Geothermal Progress Monitor Report No. 5, DOE/CE-0009/5, U.S. Department of Energy, Washington, D.C., June 1981 .

2. Assistant Secretary for Resource Applications, Division of Geothermal Energy, Geothermal Progresss Monitor Report No. 3, DOE/RA-0051, U.S. Department of Energy, Washington, D.C. March 1980 .

3. Assistant Secretary for Resource Applications, Division of Geothermal Energy, Geothermal Progress Monitor Report No. 4, DOE/RA-005, U.S. Department of Energy, Washington, D.C., September 1980.

4. Assistant Secretary for Resource Applications, Division of Geothermal Resource Management, Geothermal Progress Monitor Report No. 2, DOE/RA-0049, U.S. Department of Energy, Washington, D.C., January 1980.

5. Blake, C., and D. Entingh, GEOHEAT V3.0: An Information Management and Retrieval Systems for Geothermal Direct Heat Projects, WP-81W681, The MITRE Corporation, McLean, VA, May 1982.

6. Cohen, A., Geothermal Energy Resource Development: Reporting and Monitoring System, MTR-7307, The MITRE Corporation, McLean, VA, February 1977.

7. Entingh, D., Status of Geothermal Progress Monitoring, WP-81W714, The MITRE Corporation, McLean, VA, December 1981.

8. Entingh, D., A. Bernstein, R. Gerstein, L. Kenkeremath, and A. Gould, FORSITE: A Geothermal Site Development Monitoring and Forecasting System, MTR-82W79, The MITRE Corporation, McLean, VA (in preparation).

9. Entingh, D., R. Gerstein, and L. Kenkeremath, Estimate of U.S. Industry Investment in U.S. Geothermal Energy Activities, 1980 and 1981, WP-82W93, The MITRE Corporation, McLean, VA, February 1982 .

10. Entingh, D., A. Lopez, and E. Neham, The Geothermal Progress Monitor: Design and Implementation, MTR-80W75, The MITRE Corporation, McLean, VA, February 198I. 
11. Kenkeremath, L., and B. Walker, Draft Technical Inputs to IGCC Fifth Annual Report, WP-81W107, The MITRE Corporation, McLean, VA, February 1981.

12. Kenkeremath, L., R. Gerstein, and M. Murphy, Geothermal Progress Monitor Report No. 6,-(draft) WP-81W478, The MTTRE Corporation, McLean, VA, August 1981.

13. Kenkeremath, L., R. Gerstein, and M. Murphy, Geothermal Progress Monitor Report No. 7, (draft) WP-82W82, The MITRE Corporation, McLean, VA, January 1982.

14. Kenkeremath, L., R. Gerstein, and M. Murphy, Geothermal Progress Monitor Report No. 8, (draft) WP-82W241, The MITRE Corporation, McLean, VA, April 1982.

15. Kenkeremath, L., B. Walker, R. Gerstein, and M. Murphy, Nearterm Contributions from Geothermal Energy: Background Data on Federal Impacts, WP-81W154, The MITRE Corporation, McLean, VA, March 1981.

16. Lopez, A., D. Entingh, and E. Neham, Initial Design for the Geothermal Progress Monitor, WP-79W761, The MITRE Corporation, McLean, VA, December 1979.

17. Lopez, A., and E. Neham, Geothermal Progress Monitor Report No. 1, WP-79W761, The MITRE Corporation, McLean, VA, December 1979.

18. Neham, E., and D. Entingh, Conceptual Design of a Geothermal Site Development Forecasting System, MTR-80W72, The MITRE Corporation, McLean, VA, March 1980.

19. Walker, B., Geothermal Ethanol Plants: The Application of Moderate-Temperature Geothermal Resources to Distill Ethanol for Use as Fue1, WP-81W399, The MITRE Corporation, Mclean, VA, July 1981 . 


\section{APPENDIX}

COMMERCIAL AND TRADE PUBLICATIONS

USED BY THE GPM SYSTEM

The following is a list of the publishing offices of the trade journals and newsletters referred to in Section 3.2.

Petroleum Information Corporation

P.0. Box 2612

Suite 261-A

Denver, Colorado 80201

(303) 740-7100

Publications: National Geothermal Service (weekly)

Geothermal Well Completion Cards (monthly)

"The Geyser" Inc.

Geothermal Energy Newsletter

P.0. Box 1738

Santa Monica, California 90406

Publication: The Geyser (18 issues/year)

Geothermal Resources Council

P.0. Box 98

Davis, California 95617

Publication: The Geothermal Resources Council Bulletin (11 issues/year)

Geothermal World Corporation

5762 Firebird Court

Mission Oaks

Camarillo, California 93010

Publication: Geothermal Energy (monthly) 


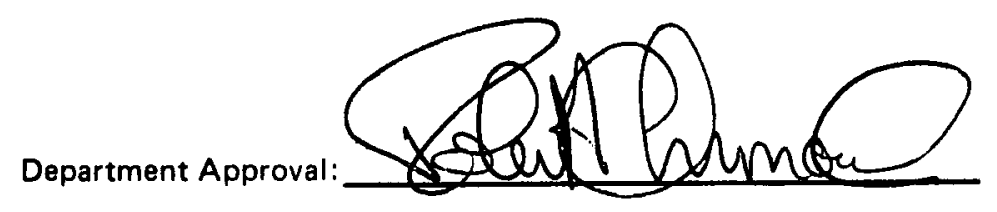

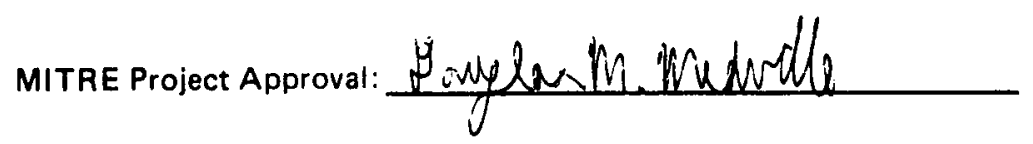

